\title{
AN ICT-BASED EXTENSION SERVICES' ADOPTION MODEL FOR PUBLIC EXTENSION OFFICERS: A CASE IN MALI*
}

\author{
Macire Kante https://orcid.org/0000-0001-5425-4549 \\ Centre National de la Recherche Scientifique et Technologique, Bamako, Mali
}

\begin{abstract}
The realization of higher yield and therefore agricultural productivity cannot be achieved without information. That information is disseminated in developing countries, particularly Mali by governmentled extension services. However, there are few (public) extension officers to disseminate that information. That makes the use of other means such as ICT one of the best ways to disseminate the extension services. This paper, firstly, looked at the drivers and challenges of the adoption of ICT based extension services by public extension officers in Mali from the literature to propose a conceptual framework. Secondly, the study assessed the survey questionnaire and thirdly, evaluated the proposed model. A sequential exploratory research design was followed. It consisted of conducting in-depth-interviews with 12 key stakeholders (agricultural scientist, policymakers, IT professional and head of extension services) in Bamako and Koulikoro. These data were analysed using computer-assisted qualitative data analysis software (RQDA) to contextualize the proposed conceptual framework. Thereafter, a survey questionnaire was designed and administered to 21 public extension officers in Bamako, Kati and Koulikoro. Quantitative data was analysed using Partial Least Square Structural Equation Modelling with the aid of the software Smartpls 3.2.8. This study validated a questionnaire of 19 items out of 26 for the next phase of the study with more respondents. Additionally, the results revealed that Relative Advantage, High Cost, Compatibility, Complexity, ICT-Skills and Policy explained $48.4 \%$ of the variance of the adoption of ICT based extension services by public extension officers.
\end{abstract}

Keywords: Agricultural extension, Productivity, ICT, adoption, Mali, Developing Countries

Manuscript first received: 2020-04-18. Manuscript accepted: 2020-10-08

Address for correspondence:

Macire Kante, Centre National de la Recherche Scientifique et Technologique, Bamako, Mali. Email: macirekante@cnrst.edu.ml

*Acknowledgement: This research was supported by the International Foundation for Science, Stockholm, Sweden, through the grant I-3-S-6199-1 number to Dr Macire Kante (CNRST). Many thanks to the participant of this study from CPS/SDR, DNA, DRA Koulikoro, AGETIC (Mali). 


\section{INTRODUCTION}

Mali is a West African country, with a population of approximately 17.735 million as of 2015 , a surface area of 1,242,248 $\mathrm{km} 2$ (INSTAT, 2015). The rural population in Mali represents about $75 \%$ of the population that works in the agriculture sector, with a literacy of about $33.1 \%$ (INSTAT, 2015). The Malian agriculture is dominated by small-scale farmers of about $68 \%$ and contributed $38.7 \%$ to the country's Gross Domestic Product in 2018 (Statista, 2019). Cereals constitute the main part of the agricultural production of the country (Aparisi \& Balie, 2013). The agricultural production is characterized by low productivity resulting in low food security level as $37.7 \%$ of the households have difficulties to nourish themselves (INSTAT, 2014). Hence, there is a need to improve the country's agricultural productivity.

Agricultural productivity's improvement could be achieved by many means. Amongst these means, there is the adoption and use of farm inputs and farm inputs information. The delivery of such farm inputs and farm input information has always been the goal of agricultural extension for the last decades (Aker, Ghosh, \& Burrell, 2016). This delivery of information, if adopted and used, may lead to the adoption and use of these farm inputs (Kante, Oboko, \& Chepken, 2017). That is the core of any extension service and the basis for the realisation higher yield. The realisation of higher yield will result in more productivity and hence more production for better food security in Mali and elsewhere.

Nevertheless, recent literature reports that (public) extension services lack resources to deliver their core activities. For instance, Akintunde and Oladele (2019) argue that extension services in developing countries face tremendous challenges to reach many and diverse farmers that require their services. One key factor of these challenges is the limited number of extension officers. That was also reported by Sanga, Kalungwizi and Msuya (2013), who argue that in most developing countries, there are few extension officers to serve many farmers. As an alternative, it was argued that the use of Information and Communication Technologies (ICTs) such as a mobile phone is one of the best ways to deliver farm inputs information to farmers (Aker et al., 2016; Sanga et al., 2013; Siyao, 2012).

Studies have been undertaken in Developing Countries to investigate the adoption and use of ICT by extension officers to disseminate farm input information towards small-scale farmers. We can, for example, cite Tanzania (Haug \& Tumbo, 2016; E T Lwoga, Stilwell, \& Ngulube, 2011; Edda Tandi Lwoga, 2010; Sanga et al., 2013), Lesotho (Akintunde \& Oladele, 2019), Mali (Kante, Oboko, \& Chepken, 2019), Kenya (Nenkari, 2011), Uganda (Kaddu, 2011) and in many others. These studies have dealt with the adoption or use of ICTs in developing countries and have reported some successes and challenges.

Nevertheless, recent data suggests that researchers up to date have tended to deal with farmers' adoption or use of ICT based extension services rather than the extension officers' adoption or use of these ICTs. Doing a systematic mapping in developing countries regarding ICT and agriculture literature, Zewge and Dittrich (2017) report 12 studies that studied the adoption of ICT (based extension) services in these countries. Over $80 \%$ of these studies looked at the adoption from the farmers' perspective. Hence, that means that extension officers (private or public) are being neglected by the literature.

On the other hand, recent data suggest that the adoption factors of ICT-based extension services by farmers are different from that of an agricultural specialist such as (public) extension officers. That point was at the basis of an ICT adoption model was developed in Iran (a developing country like Mali) for agricultural specialist (Rezaei-Moghaddam \& Salehi, 2010). Another evidence is coming 
from China, where Zhang, Wang and Duan (2016) argued that the ICT-based agricultural (extension) services in China are mainly government-led models. These points imply that the Government extension services are the most extension services disseminating extension services (agricultural information) towards farmers. Therefore, existing research has paid less attention to these government-led ICTbased extension services (adoption by public extension officers).

With regards to research in Mali on ICT-based extension services' adoption, the focus does not differ from that of the rest of the developing countries. Some studies (GSMA, 2015; Kante, Chepken, \& Oboko, 2017; Kante, Oboko, et al., 2017; Palmer, 2014) have been done on the adoption of ICTsbased extension services in Mali. However, these studies focussed on the private extension services dissemination of these ICTs and their adoption by farmers. That has resulted in less understanding and appreciation of the use of ICTs by public extension services in Mali and elsewhere. It is therefore justified, to look at ICT-based extension services' adoption from another perspective (that of the public extension officers) in Mali.

The main objective of this study was to propose an ICT-based extension services' adoption model for public extension officers in Mali.

The specific objectives were: officers

1 - To propose a conceptual model for ICT-based extension services by extension

2 - To validate the survey instrument for measuring the constructs of that proposed model

3 - To assess the proposed model

\section{LITERATURE REVIEW}

It is recognized that access and use of farm inputs, related to information on them (Kante, Oboko, et al., 2017) can improve productivity (Munyua, Adera, \& Jensen, 2009). The dissemination of farm input information is probably the best way to overcome the lack of extension officers in Mali and elsewhere. That was highlighted by Bertolini (2004) who argues that the telephone is the only ICT used (if any) by the majority of farmers in Africa. It should, therefore, be used by extension officers to deliver farm input information to these farmers.

\subsection{Factors affecting the adoption of ICTs by extension officers}

The adoption and use of ICTs by extension officers have been reported in many developing countries. Doing a literature review on Information and Communication Technologies for Agriculture (ICT4A) studies published between 2006 and 2014, Zewge and Dittrich (2017) argue that ICT supporting farmers has gained attention over the past few years with a growing number of contributions. Amongst these contributions, we can cite China (Zhang et al., 2016), Tanzania (Edda Tandi Lwoga, 2010; Siyao, 2012b), in Kenya (Nenkari, 2011; Ochilo et al., 2019; Wright et al., 2016), in Uganda (Karubanga, Kibwika, Okry, \& Sseguya, 2016), in Benin (Zoundji, Okry, Vodouhê, \& Bentley, 2016), in South Africa (Mabe \& Oladele, 2015), in Burkina Faso (Sylla, Mahama Al-Hassan, Egyir, \& Anim-Somuah, 2019), in Nigeria (Akpabio, Okon, \& Inyang, 2007) and Mali (GSMA, 2015; Kante, Oboko, et al., 2017, 2018). Hence, ICT based extension services have gained attention from researchers.

Nevertheless, there are still some challenges linked to the adoption of ICTs by extension officers 
and particularly the public officers. For instance, Mabe \& Oladele (2015) argued that for the (public) extension officers to provide more efficient, opportune and current services to farmers in South Africa, they need training and ICTs availability. Similarly, Akpabio et al. (2007) argue that public extension officers face many challenges in the adoption of ICTs such as poor enabling environment, high cost of ICTs services (airtime, data)and devices, amongst others. Moreover, the policy environment, the lack of infrastructure and ICTs' Skills were reported by Munyua et al. (2009) as the factors that affect the adoption of ICTs by agricultural extension.

\subsection{ICTs based extension services' adoption in Mali}

Extension services in Mali are mostly in the public sector. The state-owned National Directorate of Agriculture (Direction Nationale de l'Agriculture -DNA-) is the national extension service (DNA, 2012). The DNA has links with some other services that work in the agriculture sector such as the Institute of Rural Economy (Institut d'Economie Rurale - IER), National Service of Seed (Service de Semences Nationale - SSN), Malian Company for Textile Development (Compagnie Malienne pour le Développement du Textile-CMDT) and some private businesses such as Faso Kaba, Nakoshi, Comptoir 2000, Senekela, Myagro,..... The state's DNA is the only service that covers the whole country. It has an extension officer in each commune. Many studies (GSMA, 2015; Kante, Chepken, et al., 2017; Kante, Oboko, et al., 2017; Palmer, 2014) have been done on the adoption/use of ICTsbased extension services of the private sector in Mali. However, little is known about the use of modern ICTs such as mobile phone to disseminate farm input information by the public extension services. For instance, the National Directorate of Agriculture does not have an electronic platform to disseminate agricultural input information. Therefore, the questions that can be asked are: what is the use of ICTs by these services that constitute the main provider of farm input information? Is it there any progress that has been done by these services in the use of ICTs? How are they using these ICTs?

\subsection{Relevant Technology Adoption Models}

This section describes some of the relevant models for ICT on-farm (input) information adoption.

Information System (IS) Researchers utilise theories and models to investigate and explain users' use (adoption) of technology such as ICT based extension services. A literature review (Lim, Saldanha, Malladi, \& Melville, 2009) identified the ten most widely used theories in the field of IS. Regarding Information Technology and Individual behaviour, they identified five most-used theories: Technology Acceptance Modem (TAM), Theory of Reasoned Action (TRA), The Diffusion of Innovation Theory (DOI/IDT), Theory of Planned Behaviour (TPB) and the Social Cognitive Theory (SCT).

However, in the field of ICT based extension services, the Diffusion of Innovation Theory was the most widely used model. Moreover, the DOI has been advocated as being the most suitable theory for adoption studies regarding agriculture (Kante, Oboko, et al., 2018). The DOI attempts to predict the behaviour of individuals and social groups in the process of adoption (use) of innovation, considering their characteristics, social relations, time factor and the characteristics of the innovation (Tomaš-Simin \& Janković, 2014). The theory has five characteristics that determine users' adoption or use of technology: Relative Advantage, Compatibility, Complexity, Observability and Trialability (Rogers, 1995). DOI was used as the guiding theory in this study. 
Furthermore, recent data from empirical studies revealed that extension services are mainly driven by government-led models in developing countries (Zhang et al., 2016). When we speak of developing countries, it is important to talk about the resources of these governments. That means that there is a need to look for a model, which will help in dealing with Resources. Such a model is the Resource-Based View (RBV), extended to Resource-Based Theory (RBT) (Bridoux, 2003). Barney, Jr., and Wright (2011) argue that RBT has evolved from a nascent, upstart perspective to one of the most prominent and powerful theories for describing, explaining, and predicting organizational relationships. It emphasizes the firm's resources as the fundamental determinant of competitive advantage (Bridoux, 2003). This concept of 'firm' can be applied to extension services and therefore, their resource would constitute a determinant in their adoption of ICTs to deliver farm input information. Another additional point is that, as extension services operate within an environment, this environment might have an impact on their resource.

\subsection{Empirical and Theoretical Gaps}

This section provides the empirical gaps for the study. Additionally, the adoption model developed in the same settings is brought forth with their related gaps.

\section{Adoption model for farmers}

Understanding the factors related to the adoption of ICT based extension services is crucial in the design, adoption and use of these services by farmers. Researchers have been proposing such models for farmers in developing countries. Some of these models are reported below.

Such a model comes from Kante Oboko and Chepken (2018) in Mali. The scholars validated a model for small-scale cereal farmers' adoption of ICT-based agricultural input information(Figure 1). The model was based on the literature review of the existing models (Kante, Oboko, \& Chepken, 2016).

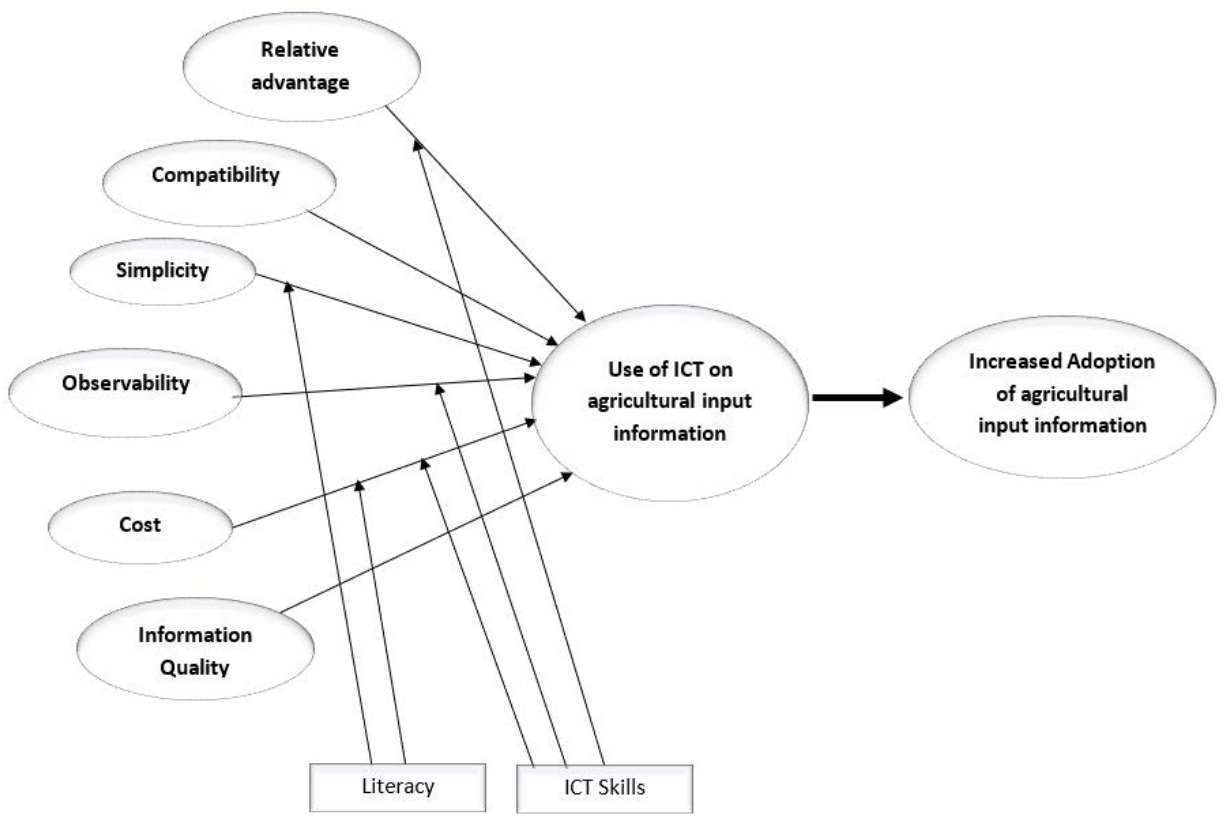

Figure 1. ICT-based agricultural input information' adoption model

Source: Kante et al. (2018).

This model has two to three gaps with regards to the current study. Firstly, this study (Kante, 
Oboko, et al., 2018) targeted farmers, whom adoption of ICT based extension services are different from that of extension officers as reported by the literature. That literature includes (Akintunde \& Oladele, 2019), who conducted a study on the adoption of ICT in Lesotho amongst extension officers. They argue that there is a significant difference in the adoption of ICTs between public and private extension officers. That point can also be applied to farmers and extension officers as reported by Rezaei-Moghaddam \& Salehi (2010), who provided an ICT based precision agriculture' adoption model for agricultural specialist. Hence, such a model could not be applied in a case where the targeted respondents are public extension officers.

Secondly, another gap of the model pointed out by themselves is that their findings could not be applied broadly as their data were collected only in one region of Mali. That points to the need for contextualization for an adoption study. That adoption will be related to both the targeted respondents of the study and the study area itself. Hence, that model is not relevant again for the current study.

As of the model of the study of Kante, Oboko, et al. (2018), many other models focused on farmers only. That makes them irrelevant for this current study. Studies focusing on only farmers adoption of ICT-based agricultural (input) information did not cover practices from (public) extension officers in Mali and elsewhere. Moreover, they did not cover the professional behaviour of these extension officers. The fact that extension officers' practices and behaviour were not covered by the study, pints to an action knowledge conflict gap. There is an action knowledge conflict gap when professional behaviour or practices deviate from research findings or are not covered by the research(Müller-Bloch \& Kranz, 2015).

\section{Adoption model for extension officers}

Some scholars looked at the adoption factors of other stakeholders such as (public) extension officers. We came across two such studies. The first one is the model from Iran (Rezaei-Moghaddam \& Salehi, 2010). That model is presented below in figure 2 .

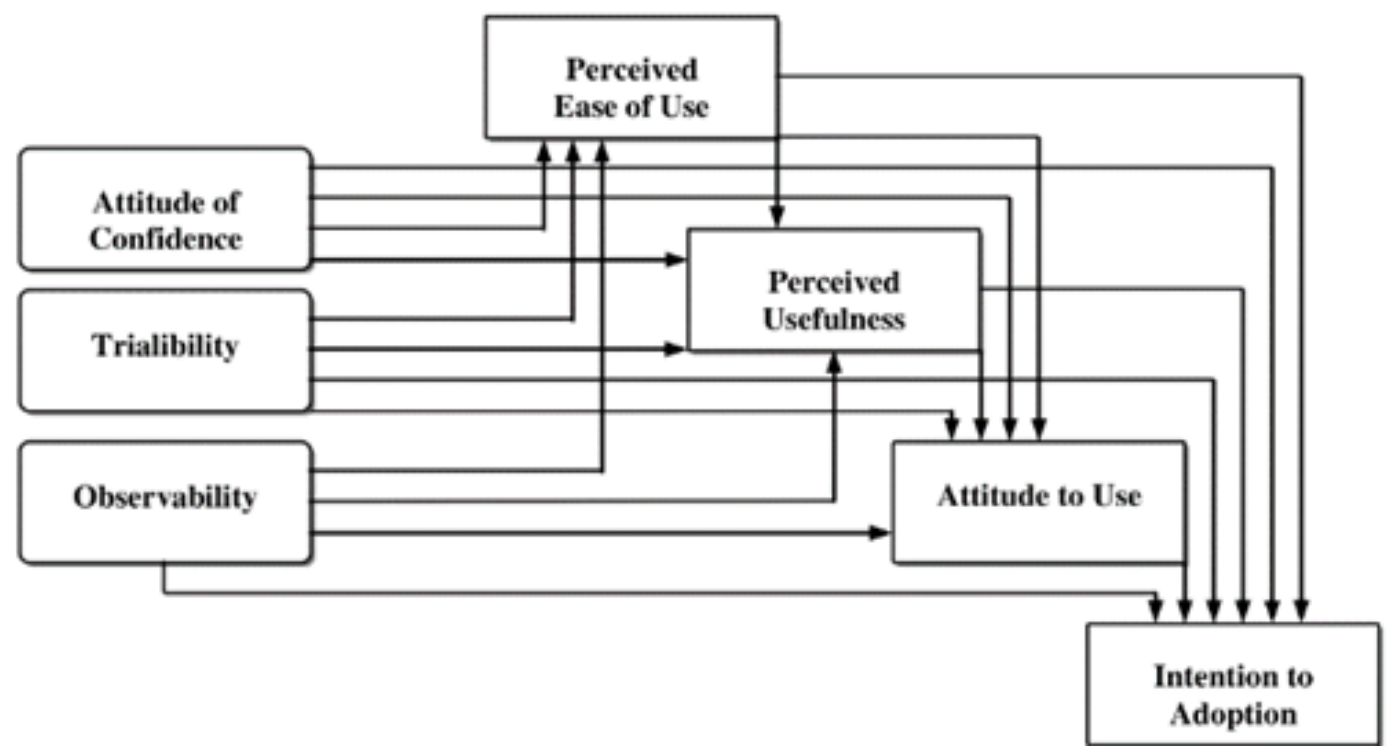

Figure 2. Conceptual Framework for agricultural specialist

Source: Rezaei-Moghaddam \& Salehi, 2010.

The results of the evaluation of the model are presented below in figure 3 . 


\begin{tabular}{lccc}
\hline Hypotheses & Path & Coefficient & P-value \\
\hline H1 & AOC $\rightarrow$ PEOU & 0.31 & 0.01 \\
H2 & AOC $\rightarrow$ ATU & 0.16 & 0.01 \\
H3 & AOC $\rightarrow$ PU & 0.04 & ns \\
H4 & AOC $\rightarrow$ INA & 0.08 & ns \\
H5 & PEOU $\rightarrow$ ATU & 0.16 & 0.01 \\
H6 & PEOU $\rightarrow$ PU & 0.23 & O \\
H7 & PEOU $\rightarrow$ INA & 0.06 & ns \\
H8 & PU $\rightarrow$ ATU & 0.18 & N \\
H9 & PU $\rightarrow$ INA & 0.08 & N \\
H10 & ATU $\rightarrow$ INA & 0.52 & 0.01 \\
H11 & OBS $\rightarrow$ PEOU & 0.16 & 0.01 \\
H12 & OBS $\rightarrow$ PU & 0.25 & 0.01 \\
H13 & OBS $\rightarrow$ ATU & 0.38 & 0.01 \\
H14 & OBS $\rightarrow$ INA & 0.14 & 0.05 \\
H15 & TRI $\rightarrow$ PEOU & 0.32 & 0.01 \\
H16 & TRI $\rightarrow$ PU & 0.11 & ns \\
H17 & TRI $\rightarrow$ ATU & 0.13 & 0.05 \\
H18 & TRI $\rightarrow$ INA & 0.16 & 0.01 \\
\hline
\end{tabular}

Figure 3. Path Coefficients and p-values of Hypotheses (Rezaei-Moghaddam \& Salehi, 2010).

As shown in Figure 3, the hypotheses H3 (Attitude of Confidence - AOC affecting Perceived Usefulness -PU), H4 (AOC affecting Intention to Adoption - INA), H7 (Perceived Ease of Use -PEOU- affecting INA), H9 (Perceived Usefulness- PU- affecting INA), H16 (Trialability -TRIaffecting PU) were not supported. That is a Knowledge void gap according to Müller-Bloch \& Kranz (2015) where the study finds something else instead of what it was looking for. Further, there is an Evaluation Void with the results of this study as the research findings or propositions need to be evaluated or empirically verified.

The second study that targeted extension officers was done by Akintunde \& Oladele (2019) in Lesotho. This study did not come up with a model but found some empirical factors driving or restraining the adoption of ICT by extension officers. The study has some gaps. The first one of such gaps is methodological. A methodological conflict gap occurs when there is a need to carry out another study to generate new insights or to avoid distorted findings. The study in Lesotho did not use any rigorous statistical method such as regression, structural equation modelling to come up with the factors. Rather, it used statistical descriptive such as means, frequencies to conclude. Hence, there is a need to further evaluate the empirical factors brought by such a study. Furthermore, another gap from the study (Akintunde \& Oladele, 2019) is the Theory application void gap, which means that Theory should be applied to certain research issues to generate new insights. However, the study did not provide any theoretical background. Thus, it is again needed to re-assess the factors.

Another study by Zoundji et al. (2016) investigated the adoption of ICTs (such as DVD) to disseminate extension services versus the traditional methods of extension services dissemination in Benin. They found that the new way to disseminate extension services (ICT) was more effective than the traditional one. However, the study did inform on the factors that motivate extension officers to use new ways of disseminating agricultural information. Again, there is a need to fill that gap by providing the factors that affect extension officers to adopt ICT-based extension services.

\subsection{Hypotheses Formulation and Conceptual Framework}

In this section, the theories that were used to come up with a conceptual framework for the study are discussed. 
Amongst the factors of the DOI, Carter \& Belanger (2004) argue that the most relevant factor are Relative Advantage, Compatibility and Complexity. In addition, the ICT based adoption study conducted in Iran find a relation between Perceived Usefulness (referred as Relative Advantage in the DOI) and Perceived Ease of Use (referred as Simplicity in the DOI) and the Adoption by agricultural specialists. Furthermore, Cultural Practices (Akintunde \& Oladele, 2019; Mabe \& Oladele, 2015), complexity of ICT (applications) (Agunga \& Putra, 2015), and the importance of the use of ICT tools for extension service delivery (Mabe \& Oladele, 2015) were amongst the factors that affect extension officers to adopt ICT for their work.

The importance of the use of ICT can be linked to the Relative Advantage (RA) of the DOI. The RA is the degree to which an innovation is perceived as better than the idea it supersedes (Rogers, 1983). Thus, RA can be referred to in this study as the degree to which ICT-based extension service appears beneficial when compared with other means of information. We therefore hypothesized that $\mathrm{H}_{1}$ 1. Relative Advantage has a positive effect on the adoption of ICTs-based farm input information by public extension officers. Cultural Practices can be labelled as Compatibility of the DOI. Compatibility is defined as the degree to which an innovation is perceived as consistent with the existing values, past experiences and needs of potential users (Rogers, 1995). Hence, we hypothesize that: $\mathrm{H}_{1} 2$. Lack of Compatibility has a negative effect on the adoption of ICTs-based extension services by public extension officers.

Complexity was a challenge to the adoption ICT based extension services in Indonesia (Agunga \& Putra, 2015) and we consequently argue that: $\mathrm{H}_{1} 3$. Complexity has a negative effect on the adoption of ICTs-based extension services by public extension officers

Other factors were reported in the literature. For instance, it was argued that serious constraints to the adoption of ICTs, as perceived by extension officers include high cost of ICT; poor basic infrastructure; non-availability of technical personnel, and failure of service (Akintunde \& Oladele, 2019; Akpabio et al., 2007; Mabe \& Oladele, 2015). Theoretically, basic infrastructure can be labelled as Government Policy. The Government Policy, in this case, refers to the means (computers, laptops, ICT-service, internet) that the State makes available for extension officers for their work. This Government Policy was hence retrieved from the RBT and hypothesized as $\mathrm{H}_{1} 4$. Government Policy posits the use of ICTs-based extension services by extension services.

The non-availability of a technical person can be labelled as Human Capital. In a study on the Challenges of ICT Adoption by South African SMEs, Harindranath \& Berna (2009) argued that some respondents reported that "We lack human skills in more technical areas of the systems; if the systems "go down" we rely on external ICT provider or consultants to assist in solving the problems". That was similar to the non-availability of technical personnel reported by Akintunde and Oladele (2019) concerning extension officers. Consequently, non-availability of technical personal was labelled as Human Capital from the RBT. In addition, the reported "lack of human skills" can also be referred to the extension officer's ICT skills. That ICTs Skills was also reported by Mabe \& Oladele (2015) as affecting the adoption of ICTs by extension officers. The hypotheses were hence formulated as:

H15. Human Capital has a significant positive effect on the adoption of ICTs-based extension services by public extension officers 
H16. ICT Skills have a significant positive effect on the adoption of ICTs-based extension services by public extension officers

As reported by the literature, High cost is a constraint for the adoption of ICT by extension officers. This high cost was relevant for farmers in Mali (Kante et al., 2019), in Benin (Adegbidi, Mensah, Vidogbena, \& Agossou, 2012) and for extension officers in Lesotho (Akintunde \& Oladele, 2019), in Nigeria (Akpabio et al., 2007). We, therefore, extract the Cost of ICT from the RBV and argue that:

H17. High Cost of ICTs have a significant negative effect on the adoption of ICTs-based extension services by public extension officers

Based on these hypotheses and the theories, the conceptual framework is displayed in figure 4.

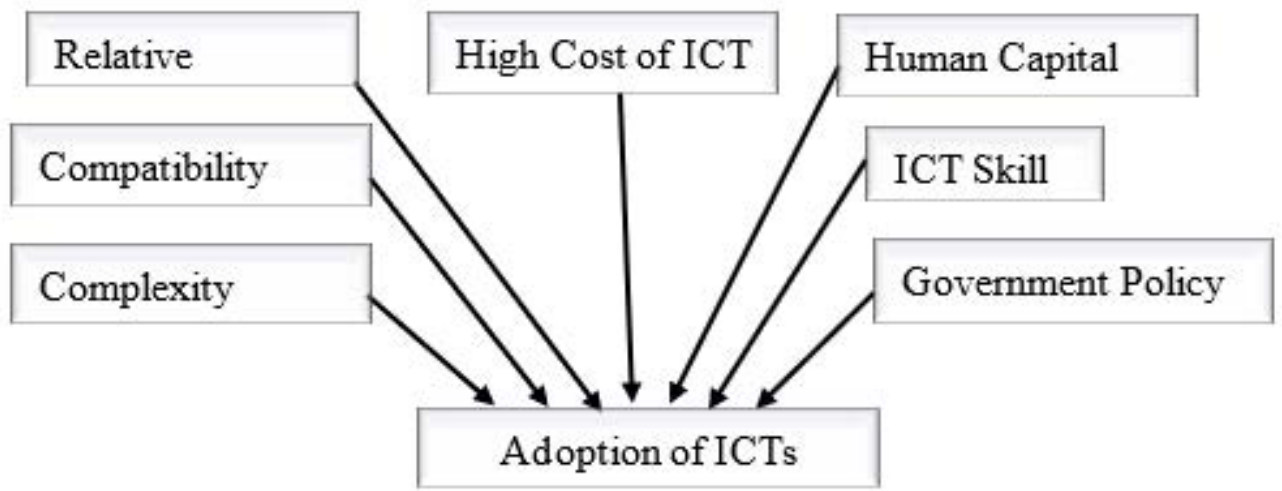

Figure 4. Conceptual Framework

\section{METHODS}

This study used a sequential exploratory research design, i.e. collected data using qualitative methods followed by a quantitative one. This mixed-method was chosen as we adopted an interpretivist paradigm, which according to Saunders (2016) aims at creating new, richer understandings and interpretations of social contexts. To do so, realist ontology and interpretivist epistemology (Tashakkori and Teddlie 2010), researchers could use quantitative analysis of published data followed by qualitative research methods to explore perceptions.

An exploratory qualitative study was carried out to assess the factors of the conceptual framework from March to May 2019. That was done to customize the research model by ensuring that it covers all the elements of public extension officers' adoption of ICT based extension services in Mali. Exploratory studies are usually conducted before undertaking quantitative methods in order to better understand the concepts of interest and hence contribute to the development of good research theories (Karuri, 2015). The qualitative pre-study was conducted through interviews around the research objectives as suggested by Fontana \& Frey (1994) with key stakeholders (agricultural scientists, policymakers, ICT professionals, head of public extension services, extension officers) involved in the public extension services. A total of 12 interviews were conducted and three were audio recorded with the informants' consent. The other nine interviews were considered as notes and observation during the interview with the respondents' consent too. 
Each interview was treated as an individual case, and the data were analysed with the RQDA computer-assisted qualitative data analysis software (CAQDAS). RQDA assisted in the qualitative analysis process by enabling easier data management, storage of the interviews' transcripts and notes, and help in coding the text. Finally, we identified patterns across categorized data and used them to draw conclusions and recommendations on factors that need to be addressed to enhance public extension officers' adoption of ICT based extension services in Mali. These conclusions and recommendations were mapped with the conceptual framework (Figure 4).

After that phase, a pilot study was undertaken to validate the research instrument of the proposed model. The objective of the pilot study was to identify and eliminate potential problems of the questionnaire e.g. grammatical and phrasing issues and validate the model predictability. That was done from June to August 2019 in Bamako and Koulikoro with 21 respondents. This sample size of 21 was enough to assess the research instruments' content validity and the model predictivity. That size was based on the literature as suggested by Garson (2016), who argues that Partial Least Square Structural Equation Modelling (PLS-SEM) can be computed even for very small samples (ex., 20). PLS-SEM is a statistical technique, which advantages include the ability to model multiple dependents as well as multiple independents; ability to handle multicollinearity among the independents; robustness in the face of data noise and missing data; and creating independent latent variables directly based on cross-products involving the response variable(s), making for stronger predictions (Garson, 2016; Kante, Chepken, \& Oboko, 2018). We used the software Smartpls 3.2.8 as it is the most comprehensive software for conducting PLS-SEM analyses (Sarstedt \& Cheah, 2019)

\section{RESULTS AND DISCUSSION}

This section presents and discusses the results.

\subsection{Keys Findings from the pre-study}

The informants recognized the great advantage and opportunity of ICT based extension services for Mali. They all noted that the current ratio of public extension officers to farmers could not permit the dissemination of extension services to farmers. And therefore, they report that these ICTs represent the (only) option for the State of Mali to disseminate extension services towards farmers in the country for more agricultural production. That point was instance argued by one of the interviewees that ".......today, it is known that the State cannot hire many extension officers. For instance, in Koulikoro, we have only 175 officers for more than 1,000 villages. Our only hope to reach these villages is the use of mobile phones.". Nevertheless, some theme of our results points to some challenges in the adoption of ICT based extension by the public extension officers in Mali. The emerging factors are discussed below.

\section{Age and Gender}

The overwhelming majority of interviewees stated that age plays an important role in the adoption of ICT based extension services. The informants reported that younger public extension officers tend to adopt more quickly these ICTs than older ones. That finding was consistent with the literature. In South Africa, for instance, Mabe \& Oladele (2015) found a significant correlation between Age and adoption of ICT by extension officers. 
With regards to Gender, with a few exceptions, most people did not believe that gender is a key determinant in the adoption of these ICTs. This is despite that $70 \%$ of the interviewees were male. This is in contrast to the finding of Mabe \& Oladele (2015) in South Africa. The explanation could be that Mabe \& Oladele (2015) used a correlation analysis. And according to Heeks (2018) correlation does not mean causality.

\section{Attitude, Opinions and Adoption}

There was a sense of attitude (of the public extension officer) playing an important role in the process of adopting ICT based extension services. Five broad concepts emerged from this theme. The first one was about the benefit that an extension officer believes that he/she could get while adopting the ICT. For instance, one interviewee said that '...attitude/perception of the officer could determine his/her adoption of ICT....". Another interviewee, when asked why some officers use ICT and others not, said that "...well, that depends on the comprehension and appreciation of everyone.......it is a new way to work". Other responses to this question included: "...it is not easier for some officers of us", "...I think that the State must provide us with the necessary resources, i.e. finance, training for us to get skilled on the use of mobile phones in our work", "for the use of e-voucher", it is mandatory for every officer to use it", "...though, it (e-voucher) is mandatory, but some officers do not use it at all.... and there is nothing that you can do about it..". A few interviewees emphasised that "the State needs to train us (public officers)..... ....it is our personal initiatives to reach farmers by mobile phones.... and sometimes, we lack airtime to do so."

\subsection{Relating the findings of the pre-study and the proposed model}

An analysis of the key findings of the pre-study linked the proposed model as shown in Table 1.

Table 1. Identified factors in the adoption of ICT based extension services

\begin{tabular}{|c|c|c|c|}
\hline Relevant Factor & From the interviews & Conceptual framework & Observation \\
\hline Complexity & Not easier; & Yes & $\begin{array}{l}\text { This empirical and theoretical factor is } \\
\text { relevant to the Malian case }\end{array}$ \\
\hline Cost & Lack of airtime & Yes & $\begin{array}{l}\text { This empirical and theoretical factor is } \\
\text { relevant to the Malian case }\end{array}$ \\
\hline Human Capital & Necessary resources & Yes & $\begin{array}{l}\text { This empirical and theoretical factor is } \\
\text { relevant to the Malian case }\end{array}$ \\
\hline ICT Skills & $\begin{array}{l}\text { get skilled on the use of mobile } \\
\text { phones }\end{array}$ & Yes & $\begin{array}{l}\text { This empirical and theoretical factor is } \\
\text { relevant to the Malian context. }\end{array}$ \\
\hline Policy & $\begin{array}{l}\text { The state must provide the } \\
\text { necessary resources; mandatory }\end{array}$ & Yes & $\begin{array}{l}\text { This empirical and theoretical factor is } \\
\text { relevant to the Malian context }\end{array}$ \\
\hline Compatibility & Mandatory; a new way to work & Yes & $\begin{array}{l}\text { This empirical and theoretical factor is } \\
\text { relevant to the Malian context }\end{array}$ \\
\hline
\end{tabular}

1 E-voucher is an ICT based extension services deployed with the Malian public extensions for the dissemination of farm input information and farm inputs towards small scale farmers. 


\subsection{Validation of the Research Instrument}

Following the confirmation of the conceptual framework, a questionnaire of 26 items was adapted from researchers (Atkinson et al., 2007; Rogers, 1995). The reliability is defined as the truthiness to which a question extends in its claim to measure what it wants to measure. Reliability assessment is the insurance that the block of items selected for a given construct is suitable operationalization for that construct in PLS-SEM. The internal consistency is used to assess the internal consistency reliability and it is preferred to the traditional Cronbach's alpha. Measurement loadings are the standardized path weights connecting the factors to the indicator variables (Garson, 2016a; Kante, Chepken, et al., 2018). Amongst the 26 items, 7 items were not loadings enough their latent variables. The path weights of these items were below 0.4 . A reliability value of 0.7 or higher is recommended, however in exploratory research, a value of 0.4 or higher is acceptable (John Hulland, 1999). The remaining 19 items, which were loading enough their latent variable, are reported in Table 2 except RAI1 (0.36). This item was not dropped as from our participant observation notes, the item should be rephrased so that it can be more understandable to the respondents.

\subsection{Assessment of the proposed model}

The assessment of a model using PLS-SEM follows two steps. The first one is assessing construct validity. The second step is to evaluate the structural model, i.e. the relationships amongst the variables.

\section{Construct validity}

Construct validity is concerned with ensuring that the measurement items selected for a given construct do indeed collectively provide a reasonable operationalization of the construct (Karuri, 2015). It is measured by establishing the Convergent Validity and Divergent Validity. Firstly, the Convergent Validity is established through the Cronbach's Alpha (above 0.6) or the Composite Reliability (above 0.6) or the Average Variance Extracted (above 0.5) (Garson, 2016; Kante, Chepken, et al., 2018). As shown in Table 2, we report the three criteria and they all point to a good convergent validity of our constructs (latent variables). Secondly, the Divergent Validity is measured through the Heterotrait-Menotrait Ratio (HTMT) or the Fornell-Larcker Criterion or the cross-loadings (Garson, 2016a; Kante, Chepken, et al., 2018). This study used the Fornel-Larcker criterion to establish the divergent validity of the variables. The criterion requires a Latent Variable to share more variance with its assigned indicators than with any other Latent Variable. The results are displayed in Table 3 below. As this criterion was satisfied, we argue that the divergent validity of the constructs was established. Summing up the convergent and divergent validity, we can conclude that the construct validity of each one of our conceptual model was established. 
Table 2. Convergent Validity

\begin{tabular}{|c|c|c|c|c|c|}
\hline Construct & Items & Indicator Reliability & Cronbach's Alpha & Composite reliability & AVE \\
\hline \multirow{3}{*}{ Compatibility } & COMP1 & 0.78 & \multirow{3}{*}{0.76} & \multirow{3}{*}{0.85} & \multirow{3}{*}{0.66} \\
\hline & COMP2 & 0.74 & & & \\
\hline & COMP3 & 0.44 & & & \\
\hline \multirow{3}{*}{ Complexity } & COMPL1 & 0.50 & \multirow{3}{*}{0.79} & \multirow{3}{*}{0.88} & \multirow{3}{*}{0.71} \\
\hline & COMPL2 & 0.80 & & & \\
\hline & COMPL3 & 0.82 & & & \\
\hline \multirow{3}{*}{ Cost } & COST1 & 0.84 & \multirow{3}{*}{0.77} & \multirow{3}{*}{0.84} & \multirow{3}{*}{0.64} \\
\hline & COST2 & 0.63 & & & \\
\hline & COST3 & 0.47 & & & \\
\hline \multirow{3}{*}{ Human Capital } & $\mathrm{HC} 1$ & 0.83 & \multirow{3}{*}{0.76} & \multirow{3}{*}{0.88} & \multirow{3}{*}{0.78} \\
\hline & $\mathrm{HC} 3$ & 0.68 & & & \\
\hline & $\mathrm{HC} 4$ & 0.46 & & & \\
\hline \multirow{2}{*}{ ICT Skills } & ICTS1 & 0.69 & \multirow{2}{*}{0.76} & \multirow{2}{*}{0.85} & \multirow{2}{*}{0.66} \\
\hline & ICTS5 & 0.68 & & & \\
\hline \multirow{2}{*}{ Policy } & POL1 & 0.63 & \multirow{2}{*}{0.54} & \multirow{2}{*}{0.81} & \multirow{2}{*}{0.68} \\
\hline & POL2 & 0.94 & & & \\
\hline \multirow{3}{*}{ Relative Advantage } & RA1 & 0.36 & \multirow{3}{*}{0.85} & \multirow{3}{*}{0.81} & \multirow{3}{*}{0.60} \\
\hline & RA2 & 0.98 & & & \\
\hline & RA3 & 0.45 & & & \\
\hline \multirow{3}{*}{ Adoption } & USE1 & 0.66 & \multirow{3}{*}{0.63} & \multirow{3}{*}{0.80} & \multirow{3}{*}{0.58} \\
\hline & USE2 & 0.89 & & & \\
\hline & USE3 & 0.72 & & & \\
\hline
\end{tabular}

Table 3. Discriminant Validity (Fornell-Larcker Criterion)

\begin{tabular}{lcccccccc}
\hline & Compatibility & Complexity & Cost & $\begin{array}{c}\text { Government } \\
\text { Policy }\end{array}$ & $\begin{array}{c}\text { Human } \\
\text { Capital }\end{array}$ & ICT Skill & $\begin{array}{c}\text { Relative } \\
\text { Advantage }\end{array}$ & Adoption \\
\hline Lack of Compatibility & 0.81 & & & & & & & \\
Complexity & 0.18 & 0.84 & & & & & & \\
High Cost & 0.41 & 0.32 & 0.80 & & & & & \\
Government Policy & -0.05 & 0.30 & 0.21 & 0.88 & & & & \\
Lack of Human & -0.08 & 0.31 & 0.17 & 0.41 & 0.81 & & & \\
Capital & 0.53 & 0.03 & 0.13 & -0.12 & -0.02 & 0.83 & & \\
ICT Skill & 0.73 & 0.07 & 0.48 & -0.17 & -0.10 & 0.32 & 0.77 & \\
Relative Advantage & 0.31 & 0.16 & 0.11 & 0.18 & 0.08 & 0.25 & 0.52 & 0.76 \\
Adoption & & & & & & &
\end{tabular}

\section{Structural Model assessment}

As stated, a PLS-SEM model assessment follow two steps. The first one was the construct validity, which was done above. The second step is the assessment of the hypotheses or the structural model. That can be done using the path coefficient $(\beta>0.100)$, the coefficient of determination $\left(\mathrm{R}^{2}\right)$ and the model predictability through the $\mathrm{Q}^{2}$ (above 0.05) (Garson, 2016; Kante, Chepken, et al., 2018). This study was exploratory and hence, we restrained ourselves from testing the hypotheses through the bootstrapping as suggested by the literature. Rather, we report the path coefficients $(\beta)$, the $\mathrm{R}^{2}$ and the model predictability $\left(\mathrm{Q}^{2}\right)$. 
Regarding the Coefficient of determination, the latent variables Relative Advantage, High Cost, Compatibility, Complexity, ICT-Skills and Policy explained $48.4 \%$ of the variance of the adoption of ICT based extension services by public extension officers. This value is substantial according to Garson (2016).

With regards to the path coefficients, as depicted in figure 5 (and hypothesised), High-Cost path coefficient towards adoption is negative $\left(\mathrm{H}_{1} 7\right)$ as well as that of Complexity on Adoption $\left(\mathrm{H}_{1} 3\right)$ and Lack of Compatibility on adoption ( $\mathrm{H}_{1} 2$.). The other latent variables, Relative Advantage, ICT Skills, Policy and Human Capital have a positive effect on the adoption of ICT based extension services. Relative Advantage has the strongest path (0.880) in the model followed by High Cost (-0.354), Policy (0.352), ICT Skills (0.222), Lack of Compatibility (-0.208) and Human Capital (0.026). This confirms the qualitative study's results that were used to form the conceptual model. There is evidence from the literature to support our findings. For instance, the Relative Advantage, Compatibility and Simplicity were found to be positively affecting the use of ICT-based agricultural input information in Mali (Kante, Oboko, et al., 2018). The poor policy was found to be a challenge in South Africa regarding the adoption of ICT by extension officers (Mabe \& Oladele, 2015). That implies that Good policy will positively affect the adoption of such ICTs, which was our point.

Regarding the predictability of our model, we run the blindfolding function of SMARTPLS 3.2.9 as suggested (Garson, 2016a; Kante, Chepken, et al., 2018) and our model passed the criterion as we got a $\mathrm{Q}^{2}$ of 0.14 . That was above the threshold of 0.05 . Hence, this model is predictive of the adoption of ICT based extension services by public extension officers.

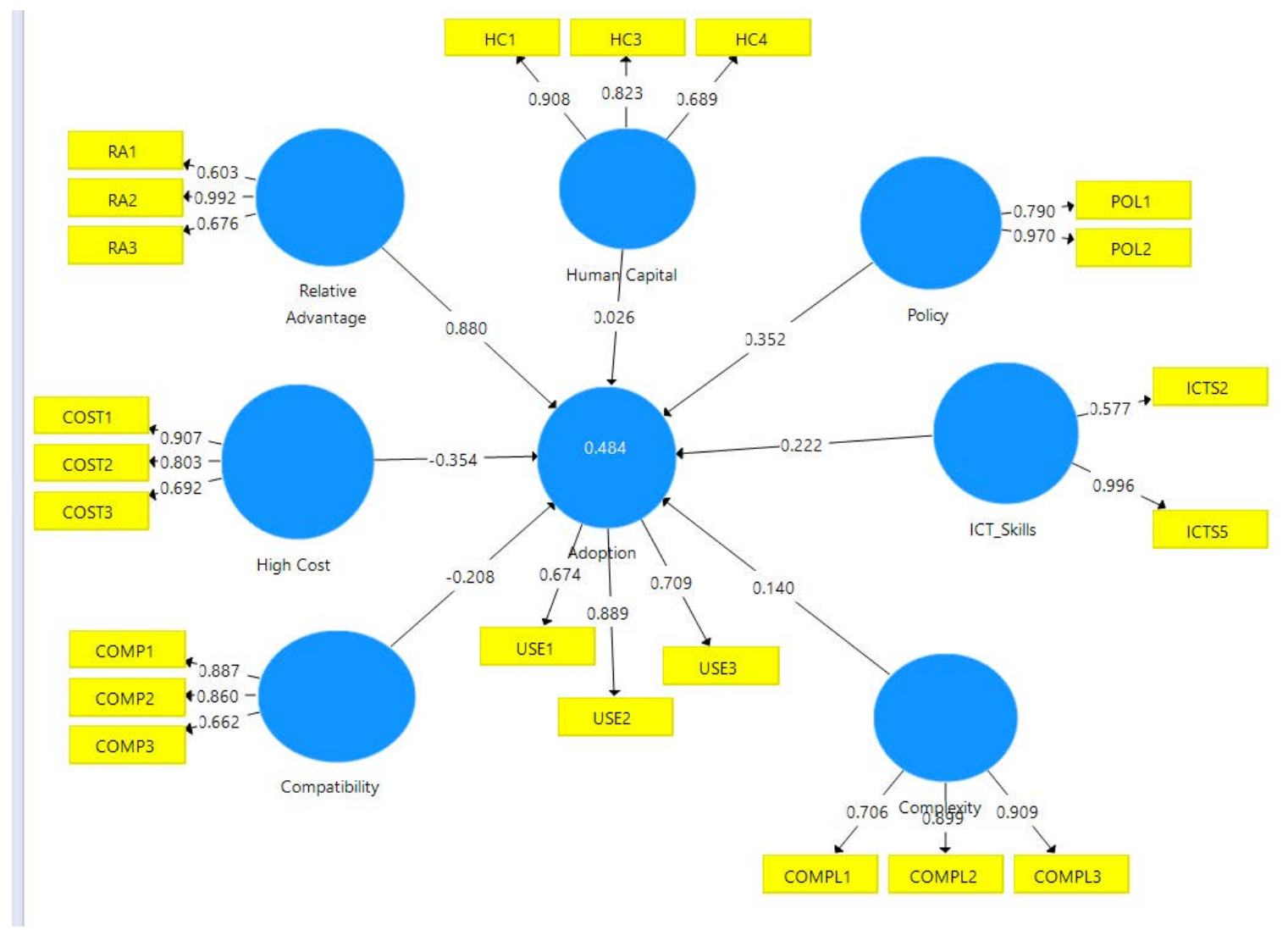

Figure 5. Model results 


\section{CONCLUSION}

This study aimed to propose an ICT-based extension services' adoption model for public extension officers in Mali. This paper discussed the results of the pre-study and the pilot-study to propose a model. It also validated the survey instrument (19 items out of 26) and constructs validity of that conceptual framework. The paper, furthermore, assessed the predictability of the proposed model. The results were useful in validating and correcting the research instruments and confirming the proposed model. The use of PLS-SEM ensured the validity and reliability of our measurement model. Although, we dropped some items to enhance the reliability and validity of the model.

However, the very small sample of this pilot-study phase could be biased. That is why we did not assess the hypotheses in terms of significance. Nonetheless, the results helped us to refine our research instrument for the next phase of this research that is to gather data from 200 public extension officers in the region of Koulikoro, Sikasso and Segou in Mali. This sample will enable us to test the hypotheses and the path coefficient significances.

\section{REFERENCES}

Adegbidi, A., Mensah, R., Vidogbena, F., \& Agossou, D. (2012). Determinants of ICT use by rice farmers in Benin : from the perception of ICT characteristics to the adoption of the technology. Journal of Research in International Business and Management, 2(11), 273-284.

Agunga, R., \& Putra, R. A. R. S. (2015). Training Needs of Indonesian Agricultural Extension Workers for the 21st Century: A Recommendation Based on a Field Study. Asian Journal of Agriculture and Development, (1362-2017-764). https://doi.org/10.22004/ag.econ.258841

Aker, J. C., Ghosh, I., \& Burrell, J. (2016). The promise (and pitfalls) of ICT for agriculture initiatives. Agricultural Economics (United Kingdom), 47, 35-48. https://doi.org/10.1111/agec.12301

Akintunde, M. A. O., \& Oladele, O. I. (2019). Use of Information Communication Technologies among Agricultural Extension Officers in Lesotho. Journal of Agricultural Extension, 23(3), 50-65.

Akpabio, I. A., Okon, D. P., \& Inyang, E. B. (2007). Constraints Affecting ICT Utilization by Agricultural Extension Officers in the Niger Delta, Nigeria. The Journal of Agricultural Education and Extension, 13(4), 263-272. https://doi.org/10.1080/13892240701630986

Atkinson, N. L., Massett, H. A., Mylks, C., Hanna, B., Deering, M. J., \& Hesse, B. W. (2007). User-Centered Research on Breast Cancer Patient Needs and Preferences of an Internet-Based Clinical Trial Matching System. J Med Internet Res. https://doi.org/10.2196/jmir.9.2.e13

Barney, J. B., Jr., D. J. K., \& Wright, M. (2011). The Future of Resource-Based Theory : Revitalization or Decline ? Journal of Management, 37(5), 1299-1315. https://doi.org/10.1177/0149206310391805

Bertolini, R. (2004). Making Information and Communication Technologies Africa. In Assuring Food and Nutrition Security in Africa by 2020: Prioritizing Actions, Strengthening Actors, and Facilitating Partnerships (pp. 1-6). Kampala: IFPRI. Retrieved from www.ifpri.org/2020africaconference

Bridoux, F. (2003). A resource-based approach to performance and competition: An Overview of the Connections between Resources and Competition. Louvain.

Carter, L., \& Belanger, F. (2004). Citizen adoption of electronic government initiatives. In System Sciences (Vol. 00, p. 10 pp.). Hawaii International: IEEE. https://doi.org/10.1109/HICSS.2004.1265306 
DNA. (2012). Ministère de l 'Agriculture République du Mali rapport bilan annuel des activités 2011. Bamako. Retrieved from http://www.fao.org/fileadmin/user_upload/spid/docs/Mali/Rapport_Annuel_2011_Mali. pdf

Garson, G. D. (2016a). Partial Least Squares: Regression \& Structural Equation Models (2016 Editi). Asheboro: Statistical Associates Publishing.

GSMA. Case study: Orange Senekela, Mali (2015). https://doi.org/10.1016/S1360-8592(98)80013-2

Harindranath, G., \& Berna, G. Challenges of ICT Adoption by South African SMEs : A study of Manufacturing and Logistics Firms, Royal University of London 1-23 (2009).

Haug, R., \& Tumbo, S. (2016). Mobile learning bridging the gap in agricultural extension service delivery: Experiences from Sokoine University of Agriculture, Tanzania Camilius Sanga and Malongo Mlozi Sokoine University of Agriculture, Tanzania. International Journal of Education and Development Using Information and Communication Technology, 12(3), 108-127.

Heeks, R. (2018). Information and Communication for Development (ICT4D) (first edit). Routledge.

INSTAT. (2014). enquête nationale auprès des ménages ( emop ) rapport d'analyse premier passage 2014 population. Bamako. Retrieved from http://www.instat-mali.org/contenu/eq/rana14pas1_eq.pdf

INSTAT. (2015). enquête nationale auprès des ménages ( emop) rapport d'analyse premier passage 2015. Bamako. Retrieved from http://www.instat-mali.org/contenu/eq/rana15pas1_eq.pdf

John Hulland. (1999). Use of Partial Least Squares (PLS) in Strategic Management Research: A Review of Four Recent Studies on JSTOR. Strategic Management Journal, 20(2), 195-204.

Kante, M., Chepken, C., \& Oboko, R. (2017). Revisitant les facteurs affectant l'utilisation des Tics sur l'information relative aux intrants agricoles par les paysans dans les pays en voie de développement. Journal of Information Systems and Technology Management, 14(2), 169-189. https://doi.org/10.4301/ S1807-17752017000200003

Kante, M., Chepken, C., \& Oboko, R. (2018). Partial Least Square Structural Equation Modelling' use in Information Systems: An Updated Guideline of Practices in Exploratory Settings. Kabarak Journal of Research \& Innovation, 6(1), 49-67. Retrieved from http://eserver.kabarak.ac.ke/ojs/

Kante, M., Oboko, R., \& Chepken, C. (2016). Factors affecting the use of ICTs on agricultural input information by farmers in developing countries. AIMS Agriculture and Food, 1(3), 315-329. https://doi.org/10.3934/ agrfood.2016.3.315

Kante, M., Oboko, R., \& Chepken, C. (2017). Influence of perception and quality of ICT-based agricultural input information on use of ICTs by farmers in developing countries: Case of Sikasso in Mali. Electronic Journal of Information Systems in Developing Countries, 83(1), 1-21. https://doi.org/10.1002/j.1681-4835.2017. tb00617.x

Kante, M., Oboko, R., \& Chepken, C. (2018). an ict model for increased adoption of agricultural input information by cereal farmers in developing countries : a case in Sikasso, Mali. University of Nairobi.

Kante, M., Oboko, R., \& Chepken, C. (2019). An ICT model for increased adoption of farm input information in developing countries: A case in Sikasso, Mali. Information Processing in Agriculture, 6(1), $26-46$. https://doi.org/10.1016/j.inpa.2018.09.002

Karubanga, G., Kibwika, P., Okry, F., \& Sseguya, H. (2016). Empowering farmers to learn and innovate through integration of video-mediated and face-to-face extension approaches: The case of rice farmers in Uganda. Cogent Food \& Agriculture, 2(1). https://doi.org/10.1080/23311932.2016.1274944 
Karuri, J. W. (2015). Determinants of Acceptance and Use of Routine HIS in Developing Countries : The Case of DHIS2 in Kenya. University of Nairobi.

Lim, S., Saldanha, T., Malladi, S., \& Melville, N. P. (2009). Theories Used in Information Systems Research : Identifying Theory Networks in Leading IS Journals. In ICIS (Ed.), International Conference on Information Systems (p. 10). AISel. Retrieved from http://aisel.aisnet.org/icis2009

Lwoga, E T, Stilwell, C., \& Ngulube, P. (2011). Access and use of agricultural information and knowledge in Tanzania. Library Review, 60(5), 383-395. https://doi.org/10.1108/00242531111135263

Lwoga, Edda Tandi. (2010). Bridging the agricultural knowledge and information divide: the case of selected telecenters and rural radio in Tanzania. Electronic Journal of Information Systems in Developing Countries, 43(6), 1-14.

Mabe, L. K., \& Oladele, I. (2015). E-Readiness Among Male and Female Extension Officers in North-West Province, South Africa. Journal of Agricultural and Food Information, 16(4), 315-325. https://doi.org/10. $1080 / 10496505.2015 .1058166$

Müller-Bloch, C., \& Kranz, J. (2015). A Framework for Rigorously Identifying Research Gaps in Qualitative Literature Reviews. In Thirty Sixth International Conference on Information Systems (pp. 1-19). ICIS.

Munyua, H., Adera, E., \& Jensen, M. (2009). Emerging ICTs and Their Potential in Revitalizing Small-Scale Agriculture in Africa. In IAAALD/AFITA/WCCA (Ed.), Agricultural Information Worldwide (pp. 3-9). Tokyo. https://doi.org/10.1196/annals.1425.034

Nenkari, H. (2011). Extension Services through Mobile Telephony and Internet in Kenya. In Extension Services through Mobile telephony and internet in Kenya. Nairobi.

Ochilo, W. N., Ruffhead, H., Rumsey, A., Chege, F., Lusweti, C., Oronje, M., \& Otieno, W. (2019). Can You Ensure that ICT for Development Apps Are Downloaded and Used? A Case Study of the Plantwise Data Collection App for Plant Health in Kenya. Journal of Agricultural and Food Information, 20(3), 237-253. https://doi.org/10.1080/10496505.2019.1609967

Palmer, T. (2014). mAgri Rapport initial sur Orange. London. Retrieved from http://www.gsma.com/ mobilefordevelopment/programme/magri/early-results-from-orange-senekela-data-and-insights-from-thebaseline-version-francaise-disponible

Rezaei-Moghaddam, K., \& Salehi, S. (2010). Agricultural specialists' intention toward precision agriculture technologies: Integrating innovation characteristics to technology acceptance model. African Journal of Agricultural Research, 5(March), 1191-1199. https://doi.org/10.5897/AJAR09.506

Rogers, E. M. (1983). DIFFUSION OF Third Edition (Third Edit). New York: Macmillan Publishing. https:// doi.org/82-70998

Rogers, E. M. (1995). Diffusion of innovations. Macmillian Publishing Co. https://doi.org/citeulike-articleid: 126680

Sanga, C. ., Kalungwizi, V. J. , \& Msuya, C. P. (2013). Building an agricultural extension services system supported by ICTs in Tanzania : Progress made, Challenges remain. International Journal of Education and Development Using Information and Communication Technology, 9(1), 80-99.

Sarstedt, M., \& Cheah, J. H. (2019). Partial least squares structural equation modeling using SmartPLS: a software review. Journal of Marketing Analytics, 7(3), 196-202. https://doi.org/10.1057/s41270-01900058-3

Siyao, P. O. (2012a). Barriers in accessing Agricultural Information in Tanzania With a Gender Perspective : the Case study of small-scale sugar Cane growers in Kilombero District. Electronic Journal of Information Systems in Developing Countries, 51(6), 1-19. 
Siyao, P. O. (2012b). Barriers in Accessing Agricultural Information in Tanzania with a Gender Perspective: The Case Study of Small-Scale Sugar Cane Growers in Kilombero District. The Electronic Journal of Information Systems in Developing Countries, 51(1), 1-19. https://doi.org/10.1002/j.1681-4835.2012. tb00363.x

Sylla, A. Y., Mahama Al-Hassan, R., Egyir, I. S., \& Anim-Somuah, H. (2019). Perceptions about quality of public and private agricultural extension in Africa: Evidence from farmers in Burkina Faso. Cogent Food \& Agriculture, 5(1), 1-14. https://doi.org/10.1080/23311932.2019.1685861

Wright, H. J., Ochilo, W., Pearson, A., Finegold, C., Oronje, M. L., Wanjohi, J., ... Rumsey, A. (2016). Using ICT to Strengthen Agricultural Extension Systems for Plant Health. Journal of Agricultural and Food Information, 17(1), 23-36. https://doi.org/10.1080/10496505.2015.1120214

Zewge, A., \& Dittrich, Y. (2017). Systematic mapping study of information technology for development in agriculture (the case of developing countries). Electronic Journal of Information Systems in Developing Countries, 82(2), 1-25. Retrieved from http://www.is.cityu.edu.hk/staff/isrobert/ejisdc/82-2.pdf

Zhang, Y., Wang, L., \& Duan, Y. (2016). Agricultural information dissemination using ICTs: A review and analysis of information dissemination models in China. Information Processing in Agriculture, 3(1), 17-29. https://doi.org/10.1016/j.inpa.2015.11.002

Zoundji, G. C., Okry, F., Vodouhê, S. D., \& Bentley, J. W. (2016). The distribution of farmer learning videos: Lessons from non-conventional dissemination networks in Benin. Cogent Food \& Agriculture, 2(1), 1-15. https://doi.org/10.1080/23311932.2016.1277838 